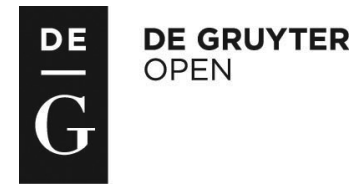

\title{
COMPARISON OF FATTY ACID COMPOSITION OF MILK FROM SIMMENTAL AND POLISH HOLSTEIN-FRIESIAN COWS IN DIFFERENT PRODUCTION SEASONS*
}

\author{
Agata Adamska, Jarosława Rutkowska`, Wiesław Przybylski
}

Faculty of Human Nutrition and Consumer Sciences, Warsaw University of Life Sciences WULS-SGGW, Nowoursynowska 159c, 02-787 Warsaw, Poland •Corresponding author: jaroslawa_rutkowska@sggw.pl

\begin{abstract}
The aim of this study was to determine the fatty acid (FA) profile of Simmental cow milk in relation to lipid intake in feeds and their composition, and to compare it with FA composition of milk from cows of Polish Holstein-Friesian (PHF) breed. To this end, 104 milk samples were collected from Simmental cows and 52 milk samples derived from PHF breed were taken over a 2-year period. The season significantly influenced both contents of lipid, dry matter and crude protein as well as FA content in lipids extracted from forages. Winter and autumn seasons were characterized by a significantly higher intake of lipids with forages resulting from the intake of fresh silages, compared with the other seasons when the animals were fed stored silages. This was reflected in the highest content of conjugated linoleic acid (CLA) $c-9 t-11$ C18:2 in milk from the autumn season. Compared with PHF, milk from Simmentals had a higher content of short-chain saturated FAs (SCSFAs) and was characterized by great differences in FA contents determined in the group of odd- and branched-chain FAs (OBCFAs). Milk from Simmental cows had the butyric acid C4:0 and $i s o$ C15:0 content of 4.99 and $1.20 \mathrm{~g} / 100 \mathrm{~g}$ FA on average, respectively, which have been associated with benefits for human health.
\end{abstract}

Key words: forage, season, Simmental cow milk, fatty acid composition, lipid intake

The composition of milk is affected mainly by feeding factors (type, quantity and quality of forage) but also by animal factors such as genetics and stage of lactation (Palmquist, 2006; Soyeurt and Gengler, 2008; Kalač and Samková, 2010). A significant part of the variability in FA composition is determined genetically (Stoop et al., 2008). Cow's breed effect on the variability of milk composition was

* The research was carried out in the framework of the research task financed by funds of the Faculty of Human Nutrition and Consumer Sciences of Warsaw University of Life Sciences for young scientist no. 505-10-10050051. 
discussed by many authors: Reklewska et al. (2005), Soyeurt et al. (2006), Barłowska (2007), Soyeurt and Gengler (2008), Škrtić et al. (2008).

The Simmental is one of the oldest breeds in Europe, most widely distributed among all breeds of cattle in the world. Total numbers of Simmental cattle are estimated between 40 and 60 million world-wide (Huyghe et al., 2014). This breed is the dual purpose cattle type (with good milk and meat traits) and is characterized by beneficial functional and health-promoting characteristics as well as resistance to atmospheric conditions, possibility of long-term use and good reproducibility (Choroszy et al., 2011). Simmental cattle came to the Podlasie area in Poland from Switzerland in the late 19th century (Pruski, 1969). The Polish Federation of Cattle Breeders and Dairy Farmers registered only about 35,000 cows into herdbooks (PFCBDF, 2012). But the Polish population of Simmental cattle has been regularly increasing since 1994. By now, the south-east region of Poland (Carpathian Foothills and Bieszczady Mountains) remains the leading region in Simmental breeding, dominated by small farms with low farming culture (Choroszy et al., 2011). Nowadays, breeders from different regions of Poland are becoming interested in this breed and many large private herds are established all over Poland (PFCBDF, 2012).

Because different countries use various breeds and feeding regimens and have different calving patterns and breeding practices, milk composition will also differ among countries (Heck et al., 2009). To the best of our knowledge, only a very limited number of studies have analyzed the FA composition of milk from Simmental cows. The breed structure of dairy cows in Poland shows that the largest group of dairy cows are those of Polish Holstein-Friesian breed (PHF, 92.55\%), followed by Simmental breed (1.53\%) (PFCBDF, 2012). This study has been undertaken to analyze the fatty acid (FA) profile of Simmental cow milk in relation to lipid intake in feeds and their composition, and to compare it with FA composition of milk from cows of Polish Holstein-Friesian breed.

\section{Material and methods}

\section{Farms and experimental conditions}

Experimental material consisted of 156 individual milk samples of 104 Simmental and 52 PHF, collected over two years (from October 2009 to September 2011) from 6 single-breed herds (1 Simmental and 5 PHF) of the Mazovia region (central part of Poland). Simmental milk samples were taken each week. Milk was collected as a pooled sample from morning and evening milking (from a collection tank, temp. $3-5^{\circ} \mathrm{C}$ ). Milk from PHF cows was taken at a frequency of two samples per month from the tank collecting milk from 5 regional producers in the studied part of the Mazovia region. The rearing conditions of Simmental and PHF (cows housed in a free-stall dairy barn) and feeding strategies were the same in each farm. Experimental farms were enrolled in official monthly test-day milk recording by the PFCBDF (2012) and their size ranged from 25 to 30 cows. Farms were similar with regard to geographical location, climate and feedstuff production procedures (pasture compo- 
sition and fertilizer application). The milk yields of Simmental and PHF breed were similar and amounted to $7100 \mathrm{~kg}$ per standard lactation. Simmental milk contained $3.55 \%$ of protein and $4.38 \%$ of fat. Whereas PHF milk contained $3.40 \%$ of protein and $4.20 \%$ of fat (PFCBDF, 2011 and 2012). In Poland, the calving pattern is allyear-round calving, non-seasonal. In the analyzed cows, the length of the calving interval and the average age of herd were similar and reached, respectively, 417 days and 6 years for the Simmental breed and 423 days and 5 years for the PHF breed.

Table 1. Composition of the feed ration ( $\mathrm{kg}$ fresh weight per cow and day) of experimental herds of cows in different seasons

\begin{tabular}{l|c|c|c|c}
\hline \multirow{2}{*}{ Forage } & \multicolumn{4}{c}{ Season } \\
\cline { 2 - 5 } & Autumn & Winter & Spring & Summer \\
\hline Corn silage & 15 & 18 & 15 & 15 \\
Hay silage & 15 & 20 & 20 & 15 \\
Hay & 1.5 & 2 & 2 & 1.5 \\
Grazed fresh grass & $5 \mathrm{x}$ & 0 & $5 \mathrm{xx}$ & 5 \\
Concentrates & 5 & 5 & 5 & 5 \\
Rapeseed meal & 0.5 & 0.5 & 0.5 & 0.5 \\
\hline
\end{tabular}

$\mathrm{x}$ - grazing at a pasture finished on 15 th October.

$\mathrm{xx}$ - grazing at a pasture started on 15th May.

Table 2. Main components of forages from different seasons

\begin{tabular}{|c|c|c|c|c|c|}
\hline \multirow{2}{*}{ Forage } & \multirow{2}{*}{ Season } & Dry matter & Crude protein & Lipids & Crude fiber \\
\hline & & $\%$ & \multicolumn{3}{|c|}{$\%$ dry matter } \\
\hline \multicolumn{6}{|l|}{ Corn silage } \\
\hline & Autumn & $47.87 \pm 2.74 \mathrm{a}$ & $5.97 \pm 0.31 \mathrm{a}$ & $3.08 \pm 0.12 \mathrm{a}$ & $19.98 \pm 0.67 \mathrm{a}$ \\
\hline & Winter & $48.20 \pm 2.21 \mathrm{a}$ & $5.98 \pm 0.28 \mathrm{a}$ & $2.29 \pm 0.08 \mathrm{~b}$ & $20.14 \pm 0.85 \mathrm{a}$ \\
\hline & Spring & $49.80 \pm 1.89 \mathrm{a}$ & $6.11 \pm 0.17 \mathrm{a}$ & $1.19 \pm 0.03 \mathrm{c}$ & $18.89 \pm 0.76 \mathrm{ab}$ \\
\hline & Summer & $53.12 \pm 2.14 \mathrm{~b}$ & $7.33 \pm 0.23 \mathrm{~b}$ & $1.73 \pm 0.08 \mathrm{ab}$ & $18.74 \pm 0.83 \mathrm{~b}$ \\
\hline \multicolumn{6}{|l|}{ Hay silage } \\
\hline & Autumn & $45.45 \pm 2.21 \mathrm{a}$ & $13.88 \pm 1.42 \mathrm{a}$ & $4.92 \pm 0.18 \mathrm{a}$ & $29.94 \pm 2.12$ \\
\hline & Winter & $45.70 \pm 1.87 \mathrm{a}$ & $13.95 \pm 0.87 \mathrm{a}$ & $3.50 \pm 0.13 \mathrm{~b}$ & $29.76 \pm 2.23$ \\
\hline & Spring & $46.08 \pm 2.12 \mathrm{a}$ & $14.30 \pm 1.23 \mathrm{ab}$ & $2.77 \pm 0.08 \mathrm{bc}$ & $29.49 \pm 1.98$ \\
\hline & Summer & $49.11 \pm 2.32 \mathrm{~b}$ & $15.17 \pm 1.21 \mathrm{~b}$ & $1.80 \pm 0.05 \mathrm{c}$ & $28.91 \pm 2.32$ \\
\hline \multicolumn{6}{|l|}{ Hay } \\
\hline & Autumn-Winter & $81.93 \pm 2.34 \mathrm{a}$ & $18.01 \pm 1.54 \mathrm{a}$ & $4.61 \pm 0.09 \mathrm{a}$ & $26.53 \pm 2.23 \mathrm{a}$ \\
\hline & Spring-Summer & $86.23 \pm 3.05 \mathrm{~b}$ & $8.77 \pm 1.47 \mathrm{~b}$ & $3.93 \pm 0.06 \mathrm{~b}$ & $30.33 \pm 1.98 \mathrm{~b}$ \\
\hline \multicolumn{6}{|c|}{ Grazed fresh grass } \\
\hline & Autumn & & & $5.25 \pm 0.05 \mathrm{a}$ & \\
\hline & Spring & & & $2.30 \pm 0.10 \mathrm{~b}$ & \\
\hline & Summer & & & $4.21 \pm 0.19 \mathrm{c}$ & \\
\hline \multicolumn{6}{|c|}{ Concentrates } \\
\hline & & $86.00 \pm 1.12$ & $18.00 \pm 0.17$ & $2.55 \pm 0.07$ & $9.50 \pm 0.10$ \\
\hline \multicolumn{6}{|c|}{ Rapeseed meal } \\
\hline & Autumn-Winter & $92.10 \pm 1.02$ & $34.10 \pm 1.45$ & $2.50 \pm 0.10$ & $13.00 \pm 1.11$ \\
\hline & Spring-Summer & $92.30 \pm 1.05$ & $34.25 \pm 1.62$ & $2.60 \pm 0.05$ & $13.40 \pm 0.86$ \\
\hline
\end{tabular}

$\mathrm{a}, \mathrm{b}, \mathrm{c}-$ values in columns with different letters differ significantly $(\mathrm{P} \leq 0.05)$. 


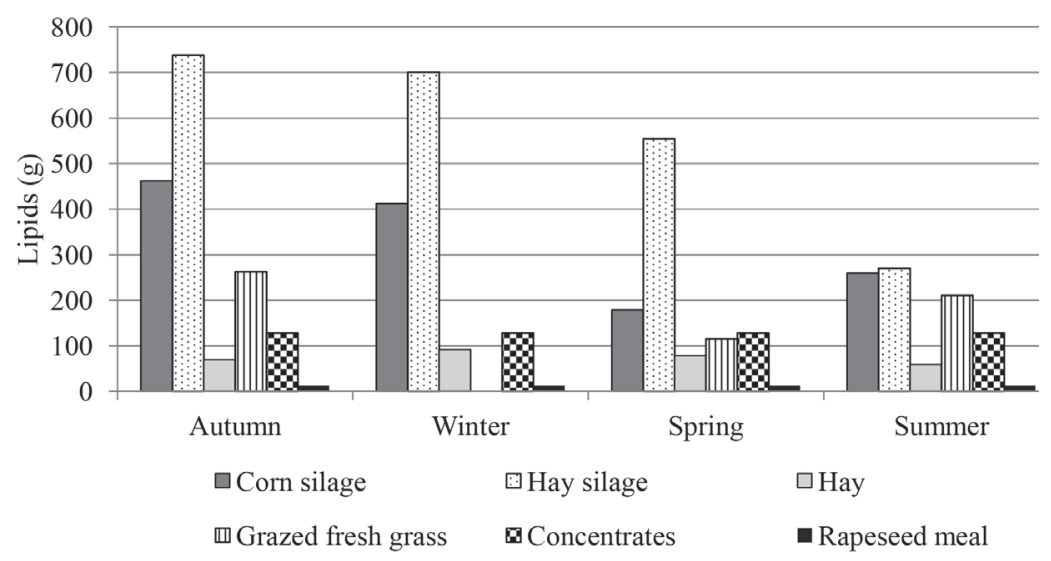

Figure 1. Intake of lipids by cows from forages (g/day)

The cows were fed according to the PMR (Partly Mixed Ration) system. Diets were prepared by a nutrition specialist and balanced according to the Nutrition Standards for Ruminants developed by the National Research Institute of Animal Production - INRA (Strzetelski, 2009). During planning of the daily rations for cows their level of milk production and the stage of lactation cycle were considered. Concentrate was given by weight manually by breeders. Feed intake was monitored every month of the experiment. To this end, the feed amount of PMR was weighed separately for each herd and the feed refusals before weighing of the next feeding. The feeding of all experimental herds of cows was based on locally grown forages (hay, grazed fresh grass, hay silage and corn silage). Only concentrate and rapeseed meal were purchased. From the 15th of May till the 15th of October the cows were pastured with high supplementation of corn and hay silages in the morning and afternoon (because of small pasture area in the farms). The detailed composition of the feed ration of the experimental herds of cows is presented in Table 1. The forages were sampled in each season. The intake of lipids from forages was estimated based on feed rations and lipid content assayed during experiment (Tables 1 and 2, Figure 1).

\section{Chemical analyses (milk and forage)}

Samples of feed components (corn silage, hay silage, hay, concentrates and rapeseed meal) were collected during the seasons, immediately frozen and stored at $-20^{\circ} \mathrm{C}$ until assayed. Pooled samples of fodder were analyzed for feed components by employing standard procedures (AOAC, 2007).

The extraction of lipids from cow's milk samples was carried out according to Röse-Gottlieb method (AOAC, 2000). Forage lipids were extracted according to Folch et al. (1957) with modification. Fatty acid methyl esters (FAMEs) were prepared according to AOCS (2000) Official Method Ce 2-66. The FAMEs of milk and 
forage lipids were analyzed by gas chromatography method (GC) using an Agilent $6890 \mathrm{~N}$ instrument (USA) equipped with a flame ionization detector, a split/splitless injector and a capillary column (Rtx 2330 with stationary phase of high polarity, $100 \mathrm{~m} \times 0.25 \mathrm{~mm}$ I.D., film thickness $0.1 \mu \mathrm{m})$. Conditions of the analysis, FA identification and estimation were as provided by Rutkowska et al. (2012 a). The content of FAs was expressed as $\mathrm{g} / 100 \mathrm{~g}$ FA.

\section{Statistical methods}

The statistical analysis was carried out using Statistica 10 software (StatSoft Inc., PL, 2011). Data were subjected to one-way analysis of variance ANOVA and Tukey's HSD post-hoc test. The differences were considered significant at $\mathrm{P} \leq 0.05$.

\section{Results}

\section{Forage composition and intake of lipids by cows}

Analyses revealed significant changes in the content of the main feed components as affected by the analyzed seasons. Elongation of silage storage caused an increase in contents of dry matter (DM) and crude protein (CP) and a decrease in lipid content (Table 2).

Generally, all forages contained substantial amounts of polyunsaturated FAs (PUFAs) (20.28-58.94 g/100 g FAs), whereas corn silage and rapeseed meal were characterized by higher amounts of monounsaturated FAs (MUFAs) compared with other forages (Table 3). Hay silage differed significantly from corn silage in the content of $\alpha$-linolenic FA $-c-9 c-12 c-15$ C18:3, i.e.: $33 \mathrm{~g} / 100 \mathrm{~g}$ FAs and $2.85 \mathrm{~g} / 100 \mathrm{~g}$ FAs on average, respectively. The content of PUFAs in silages was seasonally dependent: the highest was assayed in the autumn season: 50.70 and $58.94 \mathrm{~g} / 100 \mathrm{~g}$ FAs respectively for corn and hay silage. The concentrate contained high amounts of unsaturated FAs: linoleic (41.78 g/100 g FAs) and oleic (24.16 g/100 g FAs) (Table 3). Fresh grass was characterized by a high content of PUFAs, but the contribution of fresh grass to the diet was very low (Table 1).

The highest lipid intake from forages was noted in the autumn and winter seasons, i.e. 1671.65 and $1344.90 \mathrm{~g} /$ day, respectively (Figure 1). The highest contribution in lipid intake structure was found for silages owing to their high content in the feed ration (from $56 \%$ in the summer to $72 \%$ in the autumn). Hay and grass had a lower contribution to lipid intake structure. Although the content of lipids in these types of feed rations was significant (4.27\% in hay and $3.92 \%$ in grass, on average), their intake was low (Table 1). 


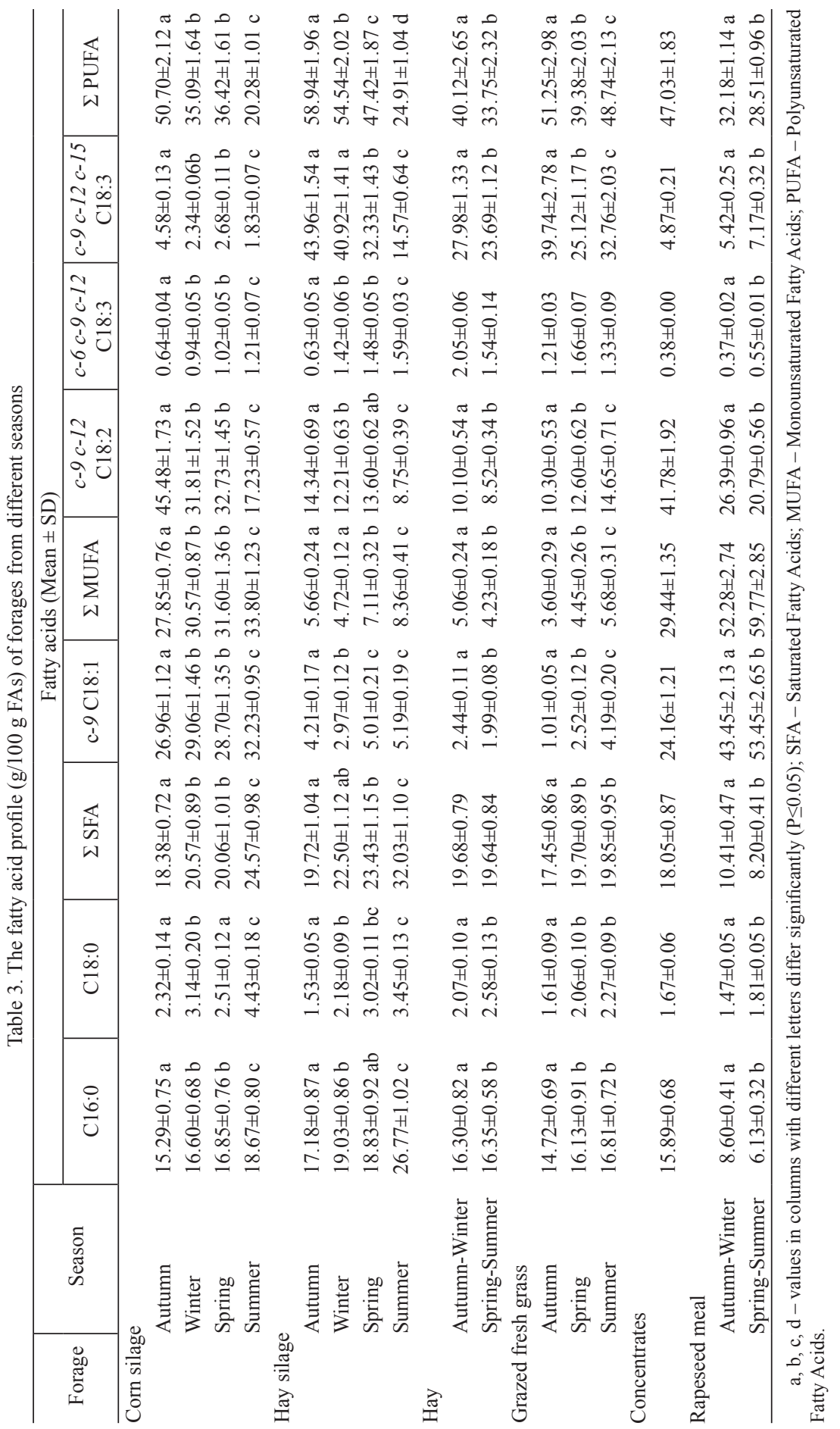




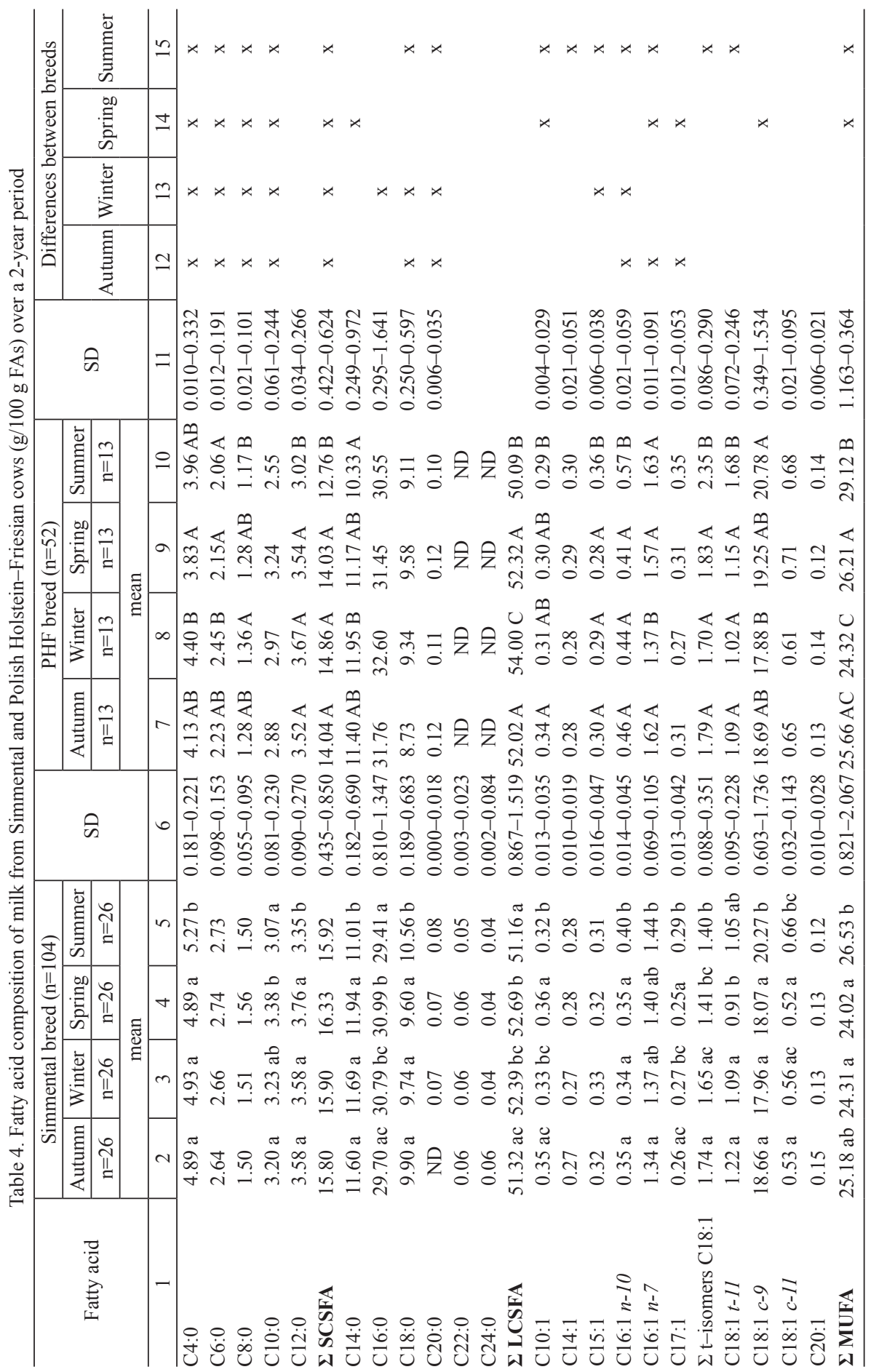




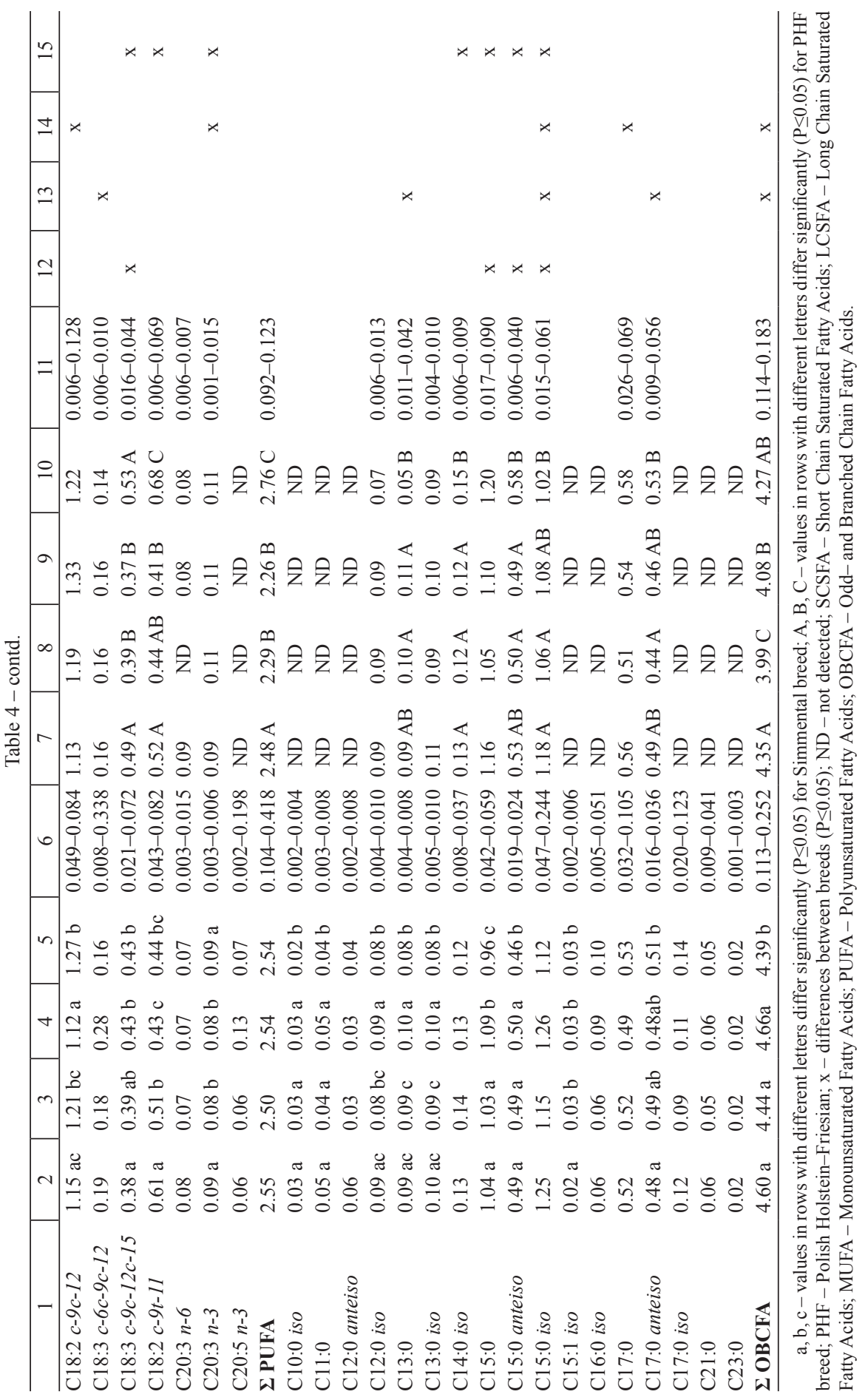




\section{Fatty acid composition of milk from Simmental and PHF cows in different production seasons}

The application of the high-resolution GC enabled determining contents of 46 FAs in Simmental milk and 35 FAs in PHF milk. The ratios of many FAs were breedand season-dependent. Analyses conducted in the milk of Simmental cows allowed identifying 17 FAs from the group of odd- and branched-chain FAs (OBCFAs), with 11 of them showing significant seasonal diversity. While in PHF milk only 9 FAs from the group of OBCFAs were detected (Table 4).

Milk samples derived from PHF breed differed significantly in all groups of FAs depending on season. Milk samples collected from the summer season contained the lowest amounts of short-chain saturated FAs (SCSFAs) and long-chain saturated FAs (LCSFAs) and the highest amounts of MUFAs and PUFAs compared with other seasons (Table 4).

\section{Discussion}

The feeding regimen of cows is probably the main factor influencing FA composition of milk (with regard to LCSFA, PUFA and OBCFA groups) (Palmquist, 2006). Many papers were devoted to using different components of cow diet in order to improve FA composition of milk (Kalač and Samková, 2010; Rutkowska et al., 2012 a; Pieszka et al., 2015; Rutkowska et al., 2015). Among animal (intrinsic) factors, the breed has a significant effect upon milk composition (Reklewska et al., 2005; Soyeurt et al., 2006; Barłowska, 2007; Škrtić et al., 2008; Barłowska et al., 2014). The previous study showed also that the stage of lactation (which was related to changes in energy status of the cow) significantly contributed to the variation in milk fat composition and altered the activity of different FA pathways (Stoop et al., 2009). Considering the above, our work was mainly devoted to the comparison of FA profile of Simmental cow milk to FA composition of milk originating from PHF cows, we also studied the composition of forages and the content of lipids ingested with forages in different seasons.

In this study, feed rations of experimental cows of both breeds were based on corn and hay silages and were supplemented mainly with hay and concentrate. Pasture feeding has a small share in the feed ration - about 12\% (Table 1). Analyses revealed changes in the content of the main components of silages during storage elongation, which caused an increase of DM and CP contents and a decrease of lipids content. Noteworthy is that the obtained decrease of lipid content in forages was up to 2-fold lower in summer forage compared with autumn season when the silages were prepared (Table 2). Seasonal changes in preserved forages were also found in other studies (Khan et al., 2009; Rutkowska et al., 2012 a; Rutkowska et al., 2012 b).

Season significantly influenced also FA composition of forages (Table 3). In preserved forages (silages and hay), the highest content of unsaturated FAs was assayed in the autumn season. After 10 months of storage, the content of unsaturated FAs decreased, for example in corn silage the content of PUFAs in the summer season 
decreased 2.5-fold compared to the autumn season. Also Kalač and Samková (2010) pointed out that forage wilting and silage aeration increase losses of unsaturated FAs, especially PUFAs. In a work by Khan et al. (2009), significant losses of $c-9 c-12 c-15$ C18:3, c-9 c-12 C18:2, c-9 C18:1 and total MUFAs were determined after silage exposure to air for $24 \mathrm{~h}$.

Regardless of the season, Simmental milk contained higher amounts of SCSFAs compared to milk fat from PHF cows (15.99 and $13.92 \mathrm{~g} / 100 \mathrm{~g}$ FAs on average, respectively). Probably because the contents of DM and CF in forages (Table 2) were similar throughout the year, it may be speculated that the intakes of cellulose by cows were the same in all seasons, which influences SCSFA concentrations in milk fat. The microbiological fermentation of fibers leads to enhanced production of acetate and $\beta$-hydroxybutyrate, being substrates for the synthesis of SCSFA in the mammary gland (Palmquist, 2006). A similar content of SCSFAs in milk of Simmental cows was determined by Barłowska (2007) and by Maurice-Van Eijndhoven et al. (2011) in milk of Dutch Friesian and Meuse-Rhine-Yssel breed. In turn, the determined values were higher than in milk originating from other breeds of cows in Poland: PHF (red-and-white strain), Jersey, Polish Red, White-and-Black, Polish Blackand-White (Barłowska, 2007; Rutkowska et al., 2012 a), and in other countries, i.e. milk from HF cows, Groningen White Headed cows and Jersey in the Netherlands (Stoop et al., 2009; Maurice-Van Eijndhoven et al., 2011). It must be emphasized that SCSFAs are valuable components of milk fat owing to their beneficial effects upon human health including anticarcinogenic properties, reduction of the risk of development of gastrointestinal disorders and cardiovascular diseases (they suppress the synthesis of VLDL and LDL lipoproteins and triacylglycerols in the liver) (Hijova and Chmelarova, 2007). In addition, they are capable of inactivating a wide group of pathogens and exert bacteriostatic effects against Helicobacter pylori (Sun et al., 2003).

Concentrations of all SCSFAs differed significantly between Simmental and PHF except for lauric acid C12:0. It is worth noting that Simmental milk was characterized by a significant content ( $5.00 \mathrm{~g} / 100 \mathrm{~g}$ FAs, average) of anticarcinogenic butyric acid C4:0 (Parodi, 2003). The content of C4:0 (4.08 g/100 g FAs) was lower in the analyzed PHF milk (Table 4). The milk of Simmental cows was also characterized by a higher content of C4:0 compared to milk originating from Dutch HF cows and other 3 cattle breeds from the Netherlands (Meuse-Rhine-Yessel, Groningen White Headed and Jersey) (Heck et al., 2012; Maurice-Van Eijndhoven et al., 2011). Slightly lesser differences were noted when comparing the analyzed milk with milk from Black-and-White breed from the mountain region in Poland $(\mathrm{C} 4: 0-3.70-4.68$ g/100 g FAs) (Rutkowska et al., 2012 a). The influence of genetic traits of cows on the extent of SCSFA synthesis in the mammary gland was described in the previous reports (Palmquist, 2006; Soyeurt and Gengler, 2008; Stoop et al., 2008).

Regarding FAs belonging to LCSFAs, Simmental milk was characterized by higher contents of $\mathrm{C} 14: 0$ and C16:0 FAs and by a lower content of C18:0, which was inconsistent with results determined for milk of the same cow breed from Slovenia (Škrtić et al., 2008). In a research by Barłowska (2007), the content of LCSFAs $(48.47 \%)$ in Simmental milk in the pasture season was lower than the mean LCSFA 
content ( $51.89 \mathrm{~g} / 100 \mathrm{~g}$ FAs) determined in our study. In the present study, significant differences between two studied breeds were found only for two FAs, namely C18:0 and C20:0 (for three seasons). Milk from PHF breed contained a lower amount of C18:0 (9.19 g/100 g FAs on average) than that from Simmental cows $(9.95 \mathrm{~g} / 100 \mathrm{~g}$ FAs on average). A lower content of FAs belonging to the LCSFA group was also determined by Rutkowska et al. (2012 a) in milk of Black-and-White breed in Poland. Simmental milk from the summer season had the lowest amount of LCSFA except for stearic acid (Table 4), because of much lower intake of lipids compared with the other seasons (Figure 1). Seasonal changes in LCSFA content in cow's milk from different breeds were also reported by many other authors (Lock and Garnsworthy, 2003; Nałęcz-Tarwacka et al., 2009; Rutkowska et al., 2012 a).

In milk fat, MUFA group is mainly represented by oleic acid $-c-9 \mathrm{C} 18: 1$. Simmental milk differed significantly in the higher content of $c-9 \mathrm{C} 18: 1$ in the summer season compared with the other seasons. It was probably caused by a higher content of MUFAs in silages in the summer season (Table 3). Although MUFAs are mostly synthesized in the mammary gland, some part of their content was derived from forages (Palmquist, 2006; Buccioni et al., 2012). A second cause for the higher $c-9$ C18:1 levels could be the higher concentration of the precursor C18:0 and a third cause could be higher activity of desaturase. A comparison of oleic acid contents in milk of Simmentals and PHF cows demonstrated significant differences only in the milk samples from the spring (Table 4). Compared to results reported by other authors, the content of $c-9$ C18:1 was higher than the values determined in milk of Black-and-White breed from the mountain region in Poland (17.89 g/100 g FAs) (Rutkowska et al., 2012 a). In turn, higher contents of this FA were determined by Lock and Garnsworthy (2003) in milk of HF cows in the UK (21.4-25.9 g/100 g FAs).

In the studied Simmental milk, the content of C18:1 trans isomers ranged from 1.40 in the summer to $1.74 \mathrm{~g} / 100 \mathrm{~g}$ FAs in the autumn. Higher contents of trans C18:1 were determined in milk of PHF cows: $2.35 \mathrm{~g} / 100 \mathrm{~g}$ FAs in the summer and $1.77 \mathrm{~g} / 100 \mathrm{~g}$ FAs on average in the remaining seasons. Also higher contents of trans C18:1 were determined in milk from Black-and-White breed from the mountain region in Poland and in milk from HF cows from the UK (Lock and Garnsworthy, 2003; Rutkowska et al., 2012 a). A characteristic trans isomer of C18:1 in milk fat is vaccenic acid $-t-11 \mathrm{C} 18: 1$ that is synthesized as a result of biohydrogenation process in the rumen and expresses documented anticarcinogenic properties (Field et al., 2009; Buccioni et al., 2012). Compared to results reported by other authors, its content determined in milk of the two breeds of cow was low (Simmental: 0.91-1.22; HF: 1.02-1.68 g/100 g FAs). A significantly higher content of vaccenic acid was determined in milk from: Black-and-White breed $(2.57 \mathrm{~g} / 100 \mathrm{~g}$ fat), Polish Red breed (2.29 g/100 g fat) and Black-and-White breed from the mountain region (Reklewska et al., 2005; Rutkowska et al., 2012 a). The lower content of vaccenic acid in the analyzed milk of Simmental and HF cows could be due to low contribution of green forage in cows' feeding (Table 1). The intake of green forage reached only $5 \mathrm{~kg}$ /day (spring - autumn), whereas in studies of other authors it accounted for 50-70 kg/day (Nałęcz-Tarwacka et al., 2009; Rutkowska et al., 2012 a). Compared 
to other reports on similar dairy cow diets, it needs to be noticed that the content of vaccenic acid in the analyzed milk of both breeds of cows was higher than in milk from the 3 Dutch breeds (Dutch Friesian - 0.704, Meuse-Rhine-Yessel - 0.975 and Jersey $-0.898 \mathrm{~g} / 100 \mathrm{~g}$ of fat) (Maurice-Van Eijnhoven et al., 2011).

In Simmental cow milk, the season had no significant influence on PUFA contentaverage $2.53 \mathrm{~g} / 100 \mathrm{~g}$ FAs despite changes in PUFA contents in the feed mixtures. In turn, in PHF cow milk analyses showed a $18 \%$ increase in PUFA content in the pasture season, especially in the summer, compared to the remaining seasons, in spite of the fact that contents of lipids and PUFAs in the main diet constituents was lower in this period. The effect of pasture feeding on increased contents of PUFAs in PHF milk was confirmed in many works (Nałęcz-Tarwacka et al., 2009; Heck et al., 2009; Rutkowska et al., 2012 a). In our study, despite a small contribution of grass in feedstuff structure, the cows were grazing on pastures for the whole summer season, compared to spring and autumn when the grazing was temporarily limited.

An exceptionally valuable intermediate product of biohydrogenation of unsaturated FAs in the rumen (which is also endogenously synthesized in the mammary gland) is CLA isomer $c-9 t-11$ C18:2, the content of which in milk of Simmental cows ranged from 0.43 to $0.61 \mathrm{~g} / 100 \mathrm{~g}$ FAs. Compared to milk of PHF cows, significant differences in the content of $c-9 t-11 \mathrm{C} 18: 2$ were found only in the summer. In view of data reported by other authors, the studied Simmental milk was characterized by a lower CLA content, especially in the summer season compared to Simmental (Reklewska et al., 2005) and HF breeds (Craninx et al., 2008). In comparison to the studies of the above authors, it needs to be emphasized that in our study the highest content of CLA in Simmental milk was assayed in the autumn, whereas the aforementioned authors reported the maximum content of CLA in the summer (as a result of pasture feeding). Heck et al. (2009) found the highest content of CLA also at the end of the summer period. The highest content of this isomer in milk in the autumn season was linked with PUFAs content in forages (fresh silages) (Table 3). Literature data indicate that a higher concentration of substrates (linoleic and linolenic acid) in the administered feed rations was the factor that stimulated the activity of rumen bacteria (Palmquist, 2006; Vlaeminck et al., 2006 b). The determined contents of CLA were higher compared to these reported by Maurice-Van Eijnhoven et. al. (2011) in milk of 3 cow breeds: Dutch Friesian - 0.297, Meuse-Rhine-Yessel 0.413 and Jersey $-0.313 \mathrm{~g} / 100 \mathrm{~g}$ of fat during the indoor housing season in the Netherlands.

A growing interest has been observed in recent years in the OBCFAs owing to their documented anticarcinogenic properties and their role as indicators of the proper function of the rumen (Vlaeminck et al., 2006 a; Fievez et al., 2012). The total content of OBCFAs determined in the analyzed milk of Simmental cows was by almost one fourth lower (on average: $4.52 \mathrm{~g} / 100 \mathrm{~g}$ FAs) than the values reported for milk samples of the Black-and-White cows from the mountain region in the pasture feeding season (Rutkowska et al., 2012 a). In this study, fresh grass constituted a small portion of the diet. In turn, statistically significant differences were noted in the case of some FAs when comparing their levels with those determined in milk of PHF cows (Table 4). The quantitatively predominating FA from the OBCFA group 
in the milk of Simmental cows was iso C15:0. Its mean content reached $1.20 \mathrm{~g} / 100 \mathrm{~g}$ FAs and was significantly higher than the values reported by other authors for milk of HF cows (Vlaeminck et al., 2006 a; Vlaeminck et al., 2006 b; Craninx et al., 2008), as well as compared to the milk from PHF cows. It needs to be emphasized that the iso C15:0 acid effectively inhibits in vitro and in vivo growth of various cancer cell lines by inducing apoptosis (Lin et al., 2012).

Another important FA from the OBCFA group is pentadecanoic acid C15:0, the mean content of which in Simmental milk reached $1.03 \mathrm{~g} / 100 \mathrm{~g}$ FAs and was comparable to the values determined by other authors in milk of HF cows (Vlaeminck et al., 2006 a; Vlaeminck et al., 2006 b; Craninx et al., 2008).

The analyzed milk of Simmental cows contained also $0.48 \mathrm{~g} / 100 \mathrm{~g}$ FAs of anteiso C15:0 acid, on average. Its content was similar to that determined by Vlaeminck et al. (2006 b), and higher compared to the value reported by Craninx et al. (2008). Contents of C17:0 and anteiso C17:0 FAs were determined at the level of 0.52 and $0.49 \mathrm{~g} / 100 \mathrm{~g}$ FAs, respectively, and were similar to these assayed by Vlaeminck et al. (2006 a) and to those reported for the analyzed milk samples of PHF breed (except for the winter season). The milk of Simmental cows was also characterized by seasonal variability of contents of other OBCFAs, i.e.: iso C10:0, C11:0, anteiso C12:0, iso $\mathrm{C} 12: 0, \mathrm{C} 21: 0$ and $\mathrm{C} 23: 0$, that were not determined in the above-cited studies (Vlaeminck et al., 2006 a; Vlaeminck et al., 2006 b; Craninx et al., 2008). The main reason for different composition of OBCFAs between Simmental and PHF breeds was the genetic effect. Heck et al. (2012) confirmed the opportunities to change the concentration of individual FA both by breeding and feeding.

In conclusion, this study revealed differences in the FA content of milk across the studied breeds. Compared to milk of cows of the PHF breed (regional samples), milk of the Simmental cows was characterized by a higher content of SCSFA. In particular, especially valuable characteristic of the FA composition of their milk is a higher content of butyric acid C4:0 than in milk of PHF cows. In addition, milk derived from Simmental cows (17FA) contained higher concentrations of FAs belonging to the OBCFA group than the milk of PHF cows (9FA), especially noteworthy is the higher content of one of the major OBCFAs - iso C15:0.

\section{References}

AOAC (2000). Official methods of analysis of AOAC International. Method number 905.02. Gravimetric method Röse-Gottlieb. USA.

AOAC (2007). Official methods of analysis of AOAC International. 18th edition, USA.

AOCS (2000). Official method of analysis of American Oil Chemists' Society. Method number Ce 2-66. Preparation of methyl esters of fatty acids. USA.

B a rło w s k J. (2007). The nutritional value and technological usefulness of milk of cows of seven breeds maintained in Poland (in Polish). Scientific Dissertation. Lublin, Poland, Publisher Academy of Agriculture, 321: 1-111.

B a rło w s k a J., L i tw iń c z u k Z., K o w a 1 M. (2014). Influence of production season and lactation stage on the technological suitability of milk from cows of various breeds fed in the TMR system. Ann. Anim. Sci., 14: 649-661. 
Buccioni A., Dec andia M., Minieri S., Molle G., Cabiddu A. (2012). Lipid metabolism in the rumen: new insights on lipolysis and biohydrogenation with an emphasis on the role of endogenous plant factors. Anim. Feed Sci. Tech., 174: 1-25.

Choros zy B., B e n e š E., Ch or o s zy Z., B rej t a W. (2011). Simmental breeding in Poland. The Polish Simmental Cattle Breeders Association. Available from URL: http://www.simentale.pl/en/ sim_pl_en.html. Accessed November 15, 2015.

Craninx M., Steen A., Van La ar H.,Van Nepsen T., Martin-Tereso J., De B a et s B., F i e v e z V. (2008). Effect of lactation stage on the odd- and branched-chain milk fatty acids of dairy cattle under grazing and indoor conditions. J. Dairy Sci., 91: 2662-2677.

F i e ld C.J., B l e w e t t H.H., P r o c t o r S., Vine D. (2009). Human health benefits of vaccenic acid. Appl. Physiol. Nutr. Metab., 34: 979-991.

Fievez V., Colman E., Castro-Montoya J.M., S tefanov I., Vlaeminick B. (2012). Milk odd- and branched-chain fatty acids as biomarkers of rumen function - an update. Anim. Feed Sci. Tech., 172: 51-65.

Folch J., Le es M., S lo an e-S t a n le y G.H. (1957). A sample method for isolation and purification of total lipids from animal tissues. J. Biol. Chem., 226: 497-509.

Heck J.M.L., van Valenberg H.J.F., Dijkstra J., van Hooijdonk A.C.M. (2009). Seasonal variation in the Dutch bovine raw milk composition. J. Dairy Sci., 92: 4745-4755.

Heck J.M.L., van Valenberg H.J.F., Bovenhuis H., Dijkstra J., van Hooijd o n k A.C.M. (2012). Characterization of milk fatty acids based on genetic and herd parameters. J. Dairy Res., 79: 39-46.

Hijova E., Chmelarova A. (2007). Short chain fatty acids and colonic health. Bratislava Med. J., 108: 354-358.

Huyghe Ch., De Vliegher A., van Gils B., Peeters A. (2014). Grasslands and herbivore production in Europe and effects of common policies. Versailles Cedex, France, Editions Quæ, $78 \mathrm{pp}$.

K a la č P., S a m k ová E. (2010). The effects of feeding various forages on fatty acid composition of bovine milk fat: A review. Czech J. Anim. Sci., 55: 521-537.

K h a n N.A., C o ne J.W., H e n d riks W.H. (2009). Stability of fatty acids in grass and maize silages after exposure to air during the feed out period. Anim. Feed Sci. Tech., 154: 183-192.

L in T., Y in X., Cai Q., F an X., Xu K., Huang L., Lu o J., Zheng J., Huang J. (2012). 13-Methyltetradecanoic acid induces mitochondrial-mediated apoptosis in human bladder cancer cells. Urol Oncol., 30: 339-345.

L ock A.L., Garnsworthy P.C. (2003). Seasonal variation in milk conjugated linoleic acid and $\Delta^{9}$-desaturase activity in dairy cows. Livest. Prod. Sci., 79: 47-59.

Maurice-Van Eijnhoven M.H.T., Hiemstra S.J., Calus M.P.L. (2011). Milk fat composition of 4 cattle breeds in the Netherlands. J. Dairy Sci., 94: 1021-1025.

Nałęcz-Tarwacka T., Grodzki H., Kuczyńska B., Zdziarski K. (2009). The influence of the ration on the content of fat fraction components in cow milk (in Polish). Med. Weter., 65: $487-491$.

P a $1 \mathrm{~m} \mathrm{qu}$ is t D.L. (2006). Milk fat: origin of fatty acids and influence of nutritional factors. In: Advanced Dairy Chemistry Vol. 2 Lipids, Fox P.F., McSweener P.L.H. (eds). Threon, New York, USA, pp. 43-80.

P a r o d i P.W. (2003). Anti-cancer agents in milk fat. Aust. J. Dairy Technol., 58: 114-118.

PFCBDF (2011, 2012). Polish Federation of Cattle Breeders and Dairy Farmers (in Polish). Available from http://www.pfhb.pl. Accessed November 15, 2013.

Pieszka M., Kamyczek M., Rudzki B., Łopuszańska-Rusek M., Pieszka M. (2015). Evaluation of the usefulness of hybrid rye in feeding Polish Holstein-Friesian dairy cows in early lactation. Ann. Anim. Sci., 15: 929-943.

Pr u s k i W. (1969). Livestock farming in the Polish Kingdom in the years 1815-1918 (in Polish). Warsaw, Poland, PWRiL, 2nd ed.

Reklewska B., B ernatowicz E., Reklewski Z., Kuczyńska B., Zdziarski K., Sak ow sk i T., S ł o n i e w s k i K. (2005). Functional components of milk produced by Polish Blackand-White, Polish Red and Simmental cows. EJPAU, 8: 1-12.

Rutk owska J., A d a m sk a A., B i a łek M. (2012 a). Fatty acid profile of the milk of cows reared in the mountain region of Poland. J. Dairy Res., 79: 469-476. 
Rutk ow ska J., S inkiew i c z I., A d a m s ka A. (2012 b). Profile of fatty acids in milk from cows fed on total mixed ration system (in Polish). Żywn. Nauk. Technol. Ja., 5: 135-144.

Rutkowska J., B i ałek M., B agni cka E., Jarczak J., Tambor K., Strzałkowska N., Jóźwik A., Krzyżewski J., Ada mska A., Rutkow ska E. (2015). Effects of replacing extracted soybean meal with rapeseed cake in corn grass silage-based diet for dairy cows. J. Dairy Res., 82: 161-168.

Škrtić Z., Levart A., Jovanovac S., Gatner V., Ko m pa n D. (2008). Fatty acid profile in milk of Busha, Cika and Simmental breed. Acta Agriculturae Slovenica, 2: 213-217.

S o ye urt H., Gengler N. (2008). Genetic variability of fatty acids in bovine milk. Biotechnol. Agron. Soc. Environ., 12: 203-210.

Soyeurt H., Dardenne P., Gillon A., Croquet C., Vanderick S., Mayeres P., Bert o z z i C., Gengler N. (2006). Variation in fatty acid contents of milk and milk fat within and across breeds. J. Dairy Sci., 89: 4858-4865.

S to o p W.M., B ovenhuis H., Heck J.M.L. van A rendonk J.A.M. (2009). Effect of lactation stage and energy status on milk fat composition of Holstein-Friesian cows. J Dairy Sci., 92: 1469-1478.

S t o o p W.M., va n A re nd on k J.A.M., H e c k J.M.L.v a n Val e n b e rg H.J.F., B o v e n hu is H. (2008). Genetic parameters for major milk fatty acids and milk production traits of Dutch HolsteinFriesians. J. Dairy Sci., 91: 385-394.

S tr ze te ls k i J. (2009). Ed. National Research Institute of Animal Production INRA Norm of Ruminant Nutrition. The nutritional value of French and national feed fur ruminants (in Polish) Kraków, Poland, Instytut Zootechniki PIB.

Sun C.Q., O'Connor Ch.J., Roberton A.M. (2003). Antibacterial actions of fatty acids and monoglycerides against Helicobacter pylori. FAMS Immunol. Med. Microbiol., 36: 9-17.

Vlaeminck B., Fievez V., Cabrita A.R.J., Fonseca A.J.M., D ewhurst R.J. (2006 a). Factors affecting odd- and branched-chain fatty acids in milk: A review. Anim. Feed Sci. Tech., 131: $389-417$.

Vlaeminck B., Fievez V., Tamminga S., Dewhurst R.J., van Vuuren A., De Brab a n d e r D., D e m e y e r D. (2006 b). Milk odd- and branched-chain fatty acids in relation to the rumen fermentation pattern. J. Dairy Sci., 89: 3954-3964.

Received: 20 I 2016

Accepted: 1 VI 2016 